\title{
Psychometric properties of the attitudes toward receiving professional psychological services scale in a sample of Iranian older adults
}

\author{
Mehdi Sharifi ${ }^{1}$, Yadollah Abolfathi Momtaz $^{2}$, Taher Alizadeh $^{3}$, Nasibeh Zanjari $^{4}$, Naseh \\ Mohammadi Safa ${ }^{5}$ \\ 1. Ph.D. Student Rehabilitation counseling, Aging Research Center and Department of Counseling, Faculty of \\ Behavioral Sciences, University of Social Welfare and Rehabilitation Sciences, Tehran, Iran. \\ 2. Assistant Professor, Aging Research Center, University of Social Welfare and Rehabilitation Sciences, Tehran, \\ Iran. \\ 3. Ph.D. Student Rehabilitation counseling, Department of Counseling, Faculty of Behavioral Sciences, University \\ of Social Welfare and Rehabilitation Sciences, Tehran, Iran. \\ 4. Assistant Professor, Aging Research Center, University of Social Welfare and Rehabilitation Sciences, Tehran, \\ Iran (Corresponding Author). \\ E-mail: zanjari.nz@gmail.com \\ 5. MSc. Student Rehabilitation counseling, Department of Counseling, Faculty of Behavioral Sciences, University \\ of Social Welfare and Rehabilitation Sciences, Tehran, Iran.
}

Received: 13/08/2019

Accepted: 20/11/2019

\begin{abstract}
Introduction: Studies show that attitude toward seeking psychological help significantly contributes to the receiving professional psychological services. Thus, measuring the attitude toward these services has been imperative for researchers and policymakers.

Aim: Regarding the lack of a proper scale, the purpose of this study was to examine the psychometric properties of the attitudes toward receiving professional psychological services scale-short form (ATSPPH-S) among the Iranian older adults.
\end{abstract}

Method: This cross-sectional (descriptive) study using a multistage cluster sampling technique was conducted on a sample of 200 community-dwelling people aged 60 years and above in Tehran city. Psychometric evaluation of ATSPPH-S was assessed through face validity and confirmatory factor analysis. The WHO well-being scale (WHO-5) was employed for predictive validity. Moreover, internal consistency reliability was examined by Cronbach's alpha.

Results: Face validity of the scale was accepted by the expert panel after reviewing and revising. The scale had a significant and positive correlation with WHO-5( $\mathrm{r}=0.26)$. The CFA revealed that the ATSPPH-S structure was a valid model $(\mathrm{CMIN}=2.229, \mathrm{GFI}=0.929, \mathrm{CFI}=0.943, \mathrm{RMSEA}$ $=0.079)$. The ATSPPH-S Cronbach's alpha was 0.84 .

Conclusion: The results showed ATSPPH-S is a valid and reliable scale for measuring attitude toward receiving mental health services among Iranian older adults. Therefore, the ATSPPH-S can be used in future research after more consideration.

Keywords: Psychometric, Attitude, Mental health services, Older adults, Iran

\footnotetext{
How to cite this article : Sharifi M, Abolfathi Momtaz Y, Alizadeh T, Zanjari N, Mohammadi Safa N. Psychometric properties of the attitudes toward receiving professional psychological services scale in a sample of Iranian older adults. Shenakht Journal of Psychology and Psychiatry. 2019; 6 (5): 83-95 .URL: http://shenakht.muk.ac.ir/article-1-806-fa.pdf
}

Copyright $@ 2018$ the Author (s). Published by Kurdistan University of Medical Sciences. This is an open access article distributed under the terms of the Creative Commons Attribution-Non Commercial License 4.0 (CCBY-NC), where it is permissible to download, share, remix, transform, and buildup the work provided it is properly cited. The work cannot be used commercially without permission from the journal. 


\title{
ويخٔى هاى روانسنجى مقياس نكر ش نسبت به دريافت خدمات روانشناختى حرفهاى در ذمونهاى از سالمندان ايرانى سئى
}

\begin{abstract}
مهدى شريفى'، يداله ابوالفتحى ممتاز '، طاهر عليز ادهّ، نسيبه زنجرى"، ناصح محمدى صفاه ا - دانشجوى د كترى مشاوره تو انبخشى، مركز تحقيقات سالمندى و گروه آموزشى مشاوره، دانشكده علوم رفتارى، دانشخاه علوم بهزيستى و توانبخى، تهر ان،

r- استاديار، مر كز تحقيقات سالمندى، دانشگاه علوم بهز يستى و تو انبخشى، تهران، ايران.

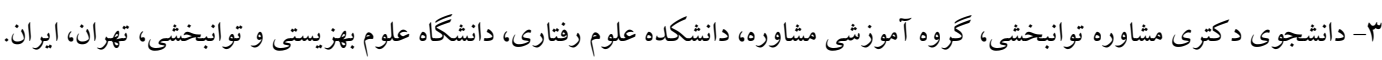

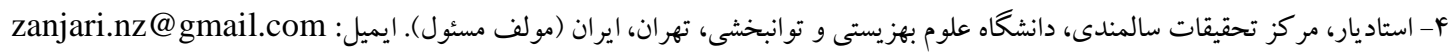

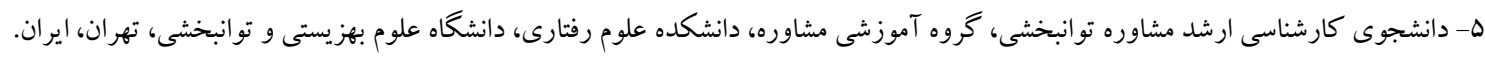

تاريخ پذيرش مقاله:

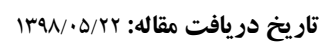

جִكيده

مقدمه: مطالعات نشان داده اند كه تمايل نسبت به دريافت خدمات روانشناختى به طور معنادارى در دريافت خدمات روانشناختى

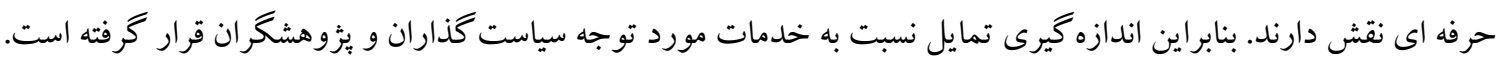

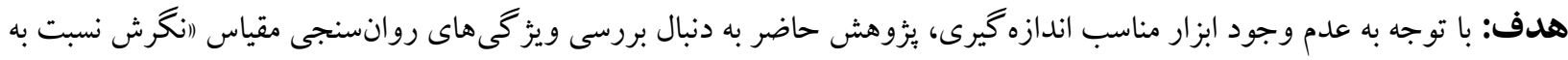
دريافت خدمات روانشناختى حرفهاى" در سالمندان ايرانى بود.

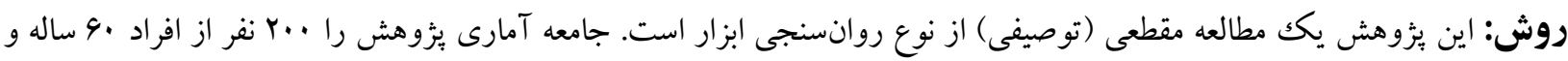

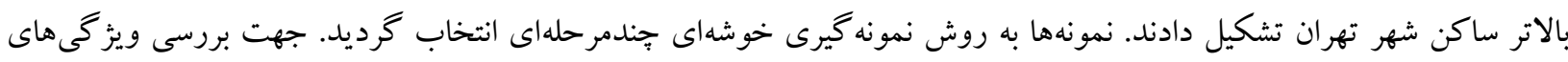

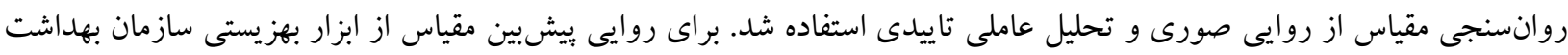

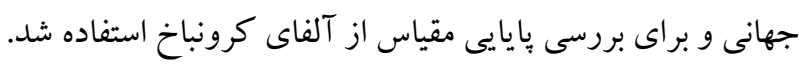

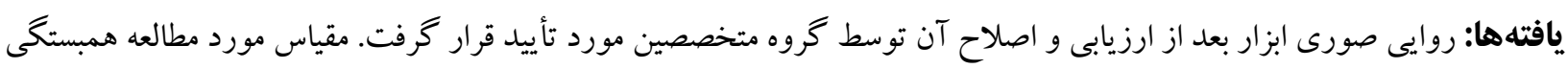

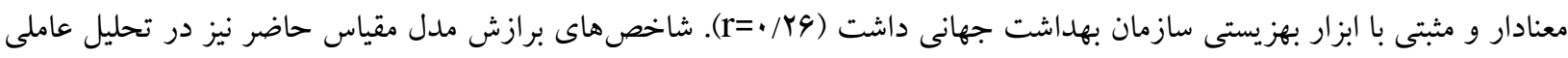
تأييدى مناسب بود (CMIN=r/rYq

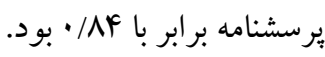
نتيجه كيرى: نتايج بثوهش نشان داد كه برسشنامه مورد بررسى مقياسى بايا و روا برودا براى سنجش نكرش سالمندان ايرانى نسبت به

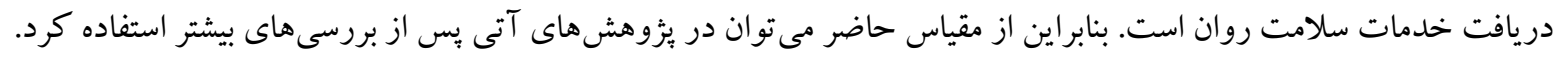

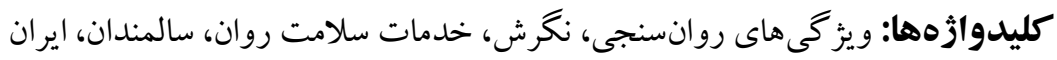


كمتر به دنبال درمان حرفهاى سلامت روان مىروند

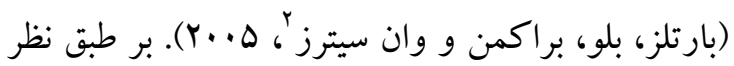

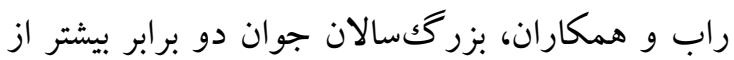
سالمندان توسط متخصصان سلامت روان ويزيت مىشوند و همجنين آكاهى بيشترى درباره موضوعات

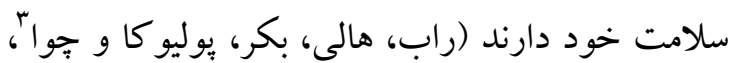
r.r. (Y). به لحاظ جنسيتى نيز مطالعاتى تأييد كردهاند كه زنان نسبت به مردان نكرش بيشترى نسبت به دريافت خدمات روان شناختى حرفهاى دارند (الهايى، شواينل و

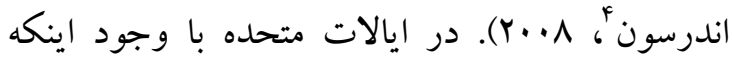
افراد سالمند به سرعت در حال افزايش هستند، بيمارىهاى روانى درمان نشده در ميان اين جمعيت

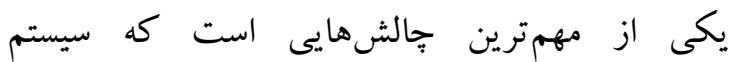
ارائهدهند گان خدمات سلامت روان با آن مواجه هستند و اين در حالى است كه تركيبى از رواندرمانى و روانيزشكى در درمان اختلالات روانى در ميان افراد سالمند و ارائه مشاوره در اين خصوص بسيار مؤثر

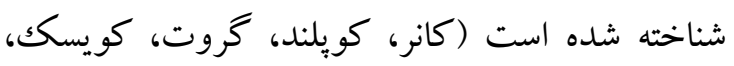

$$
\text { روزن، رينولدز و براونه، س... (Y). }
$$

برخى از موانع درونى خاص كه مانع از مراجعه افراد

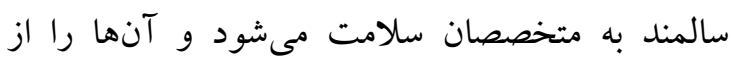
كرفتن خدمات مشاورهاى باز مىدارد عبارتاند از:

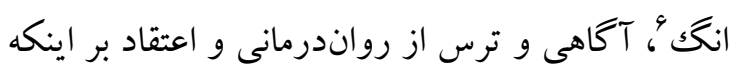
علائم موجود به خصوص علائم افسردگى در اين دوران طبيعى هستند؛ اما در مقابل عو امل ديخرى هستند

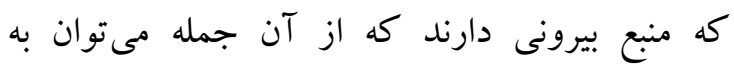
نكر انىهاى مربوط به هزينه و بيمه، تبعيض سنى، عدم

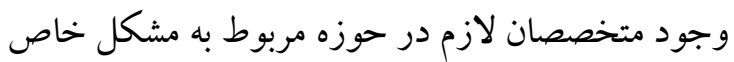
افراد سالمند و مشكلات رفتووآمد اشاره نمود (ييين،

2 . Bartels, Blow, Brockmann \& Van Citters

. Robb, Haley, Becker, Polivka \& Chwa

. Elhai, Schweinle \& Anderson

5 . Conner, Copeland, Grote, Koeske, Rosen, Reynolds \& Brown 6. Stigma

\section{مقلدمه}

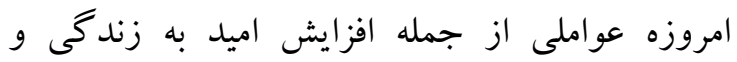

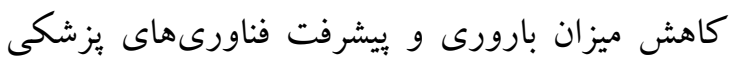
باعث افزايش جمعيت سالمندان در سراسر جهان كرديده است؛ به گونهاى كه سالمند شدن جهان به به

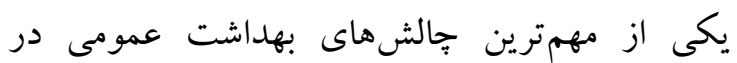
سالهاى اخير تبديل شده است (اسمانويج- تانستروم،

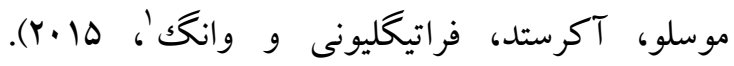

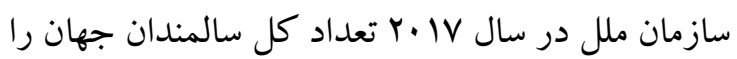
حدود بوه ميليون ذكر كرده و ييشبينى مىشود اين تعداد در سال •ه·r به دو ميليارد نفر خواهد رسيد كه دو سوم اين جمعيت در كشورهاى در حال توسعه زندكى خواهند كرد (دارابى و ترابى، IV إY). در ايران نيز بررسىها و شاخصهاى آمارى حكايت از رشد يرشتاب جمعيت سالمند دارد؛ به طورى كه در

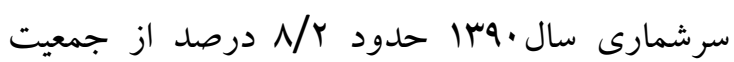
ايران را افراد بالاى •9 سال تشكيل مىدادند (كوشيار، شوروزى، دلير و حسينى، ها +r) كه اين نسبت در سال ه9 به حدود ب, 9 درصد افزايش يافته است و بيشبينى مىشود كه تا سال . rعا حدود يكك جهارم از جمعيت كشور را جمعيت سالمندان تشكيل بدهند (مركز آمار

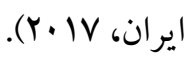

تغيير شرايط زندگى و فرايندهاى مرتبط با سالمندى، افراد سالخورده را در معرض بسيارى از اختلالات روانى، فيزيكى و اجتماعى قرار مىدهد (علوى، خادم

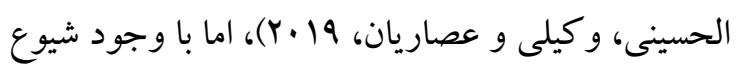
بالاى اين اختلالات در ميان افراد سالمند، تعداد كمى لـى از اين جمعيت به متخصصان سلامت روان براى درمان جهت مشاوره و ديخر خدمات مراجعه مى كنند و در

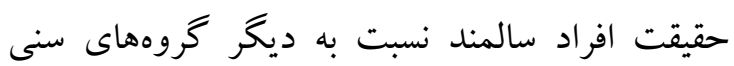

${ }^{1}$. Osmanovic-Thunström, Mossello, Åkerstedt, Fratiglioni, \& Wang 
روشهاى بيشرفته آمارى و روانسنجى مورد بررسى

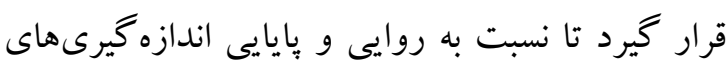
حاصل از آنها اطمينان و اعتماد كافى حاصل شود (كاستا و مك كرى" (1991). مطالعه نخرش نسبت به دريافت خدمات روانشناختى حرفهاى در ايران حوزهاى بديع و تازه است و تاكنون

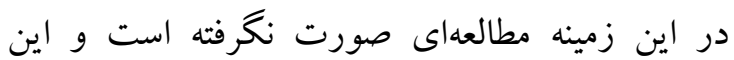
يزٔوهش جزء معدود بززوهشهايى است كه در ايران به

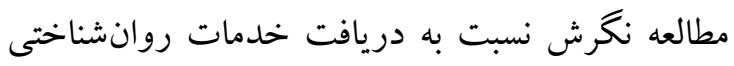

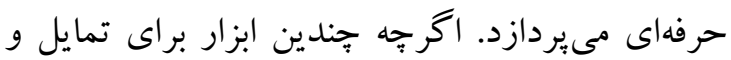

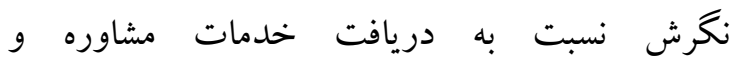
روانشناختى در سطح دنيا وجود دارد اما مرتبطترين و

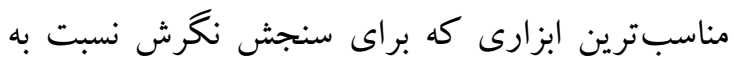
كمككهاى مشاورهاى و خدمات روانى وجود دارد، نخرش نسبت به دريافت خدمات روانشناختى حرفهاى - فرم كوتاه ب' (ATSPPH-S) است. به نظر مىرسد اين مقياس، ابزار مناسبى جهت بررسى نكرش سالمندان

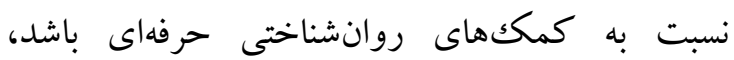
جر اكه اولاً مزيت اين مقياس نسبت به مقياس هاى مشابه كوتاه بودن آن است، دوماً اين مقياس وير كاربردترين

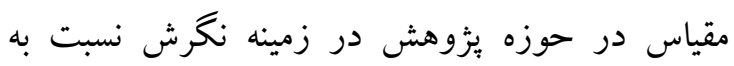
كمككهاى روانشناختى حرفهاى است. عدم استفاده از خدمات مشاورهاى به خصوص در حوزه روانى براى افراد سالمند به جِند دليل مى تواند نكر ان كننده باشد. اول اينكه جمعيت سالمندان در دنيا و وراد به خصوص در ايران رشد شتاب گونهاى دارد و دوم

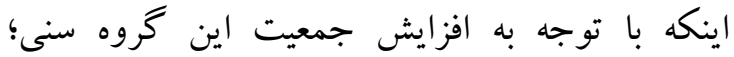

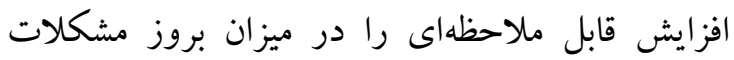
مربوط به سلامت به خصوص سلامت روانى شاهد خواهيم بود (مركز آمار ايران، YV). سوم با توجه به

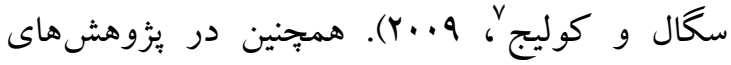

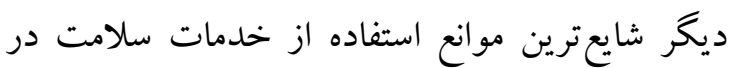
ميان افراد سالمند، عدم مقرون به صرفه بودن مراقبت،

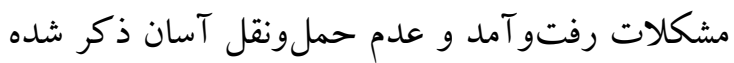

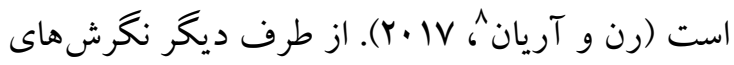
منفى نسبت به درمانهاى روانشناختى به طور قابل ملاحظهاى روى رفتار كمكك خواهانه تأثير مى گذارد.

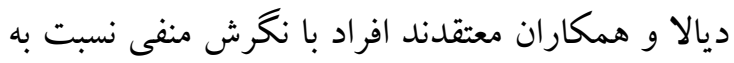
درمان، نسبت به افرادى كه نخرش مثبت دارند ينج برابر كمتر به دنبال خدمات مربوط به سلامت مىروند (ديالا، مانتانر، والراس، نيكرسون، لاويست و ليف،

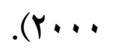

تصميم براى دريافت خدمات حرفهاى براى مشكلات

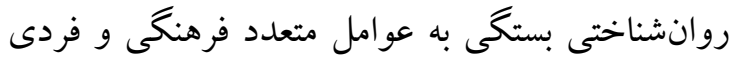

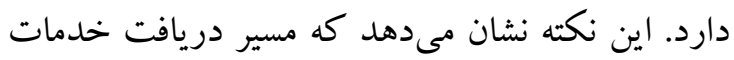
روانشناختى حرفهاى از يكك نقطه مشخص در شبكه اجتماعى شروع مىشود و سبس تعاملات كمك

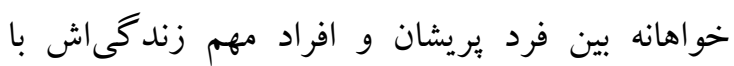

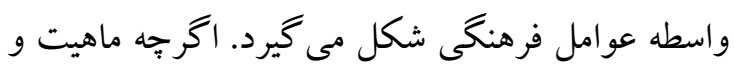
شدت اين آشفتكى موجب شده است كه فرد بريشان به

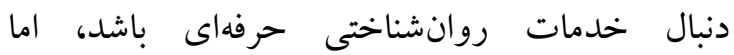

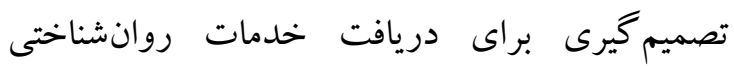
حرفهاى، بستخى به عوامل متعدد فردى و فرهنگى دارد

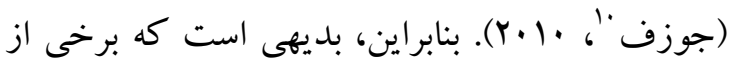

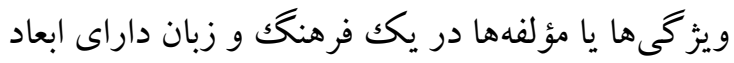

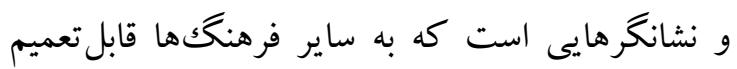
نيست. از اينرو، ضرورى است كه ابزارها و آزمونها

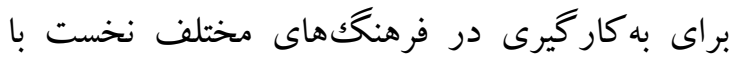
دقت و وسواس علمى انتخاب شود و سيس با

\footnotetext{
. Pepin, Segal \& Coolidge

8 . Renn \& Areán

${ }^{9}$. Diala, Muntaner, Walrath, Nickerson, LaVeist \& Leaf ${ }^{10}$. Joseph
} 
پاركها و مراكز تفريحى و تجارى محلات انتخاب شده مراجعه كردهاند، يرسيده شد. حجم نمونه ب.. نفر، جهت بررسى روايى و يايايى ابزار يزوهش مدنظر قرار گرفت. بدين صورت كه در اين يزوهش با توجه به اينكه تعداد سؤالات مقياس ·ـ كويه بود، به ازاى هر سؤال برسشنامه ·. نفر در نظر گرفته شد. جֶنانكه در بعضى يزوهشها با توجه به تعداد سؤالات ابزار مورد يُزوهش، به ازاى هر سؤال، تعداد ·. نفر رانيز مناسب

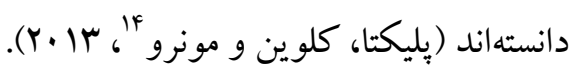
بس از تهيه نسخه انخليسى مقياس و دريافت اجازه ترجمه از نويسنده مقياس، از روش ترجمه-باز ترجمه جهت ترجمه و روانسنجى مقياس استفاده شد. به اين صورت كه در ابتدا مقياس توسط دو مترجم مسلط به زبان انخليسى ترجمه و نسخه اوليه فارسى استخر اج شد. ״ّ از ترجمه ابزار به زبان فارسى، براى بررسى روايى ظاهرى مقياس در مرحله اول در سطح آيتمها از نظر وضوح و سادگى و قابل فهم بودن و در مرحله دوم در سطح يرسشنامه از نظر مناسب بودن ترجمه براى جامعه ايران، روشن بودن و مناسب بودن براى سنجش عوامل محيطى توسط ·ل استاد مجرب حوزه سالمند شناسى، روانشناسى و مشاوره مورد تحليل و ارزيابى قرار كرفت. در ادامه يس از برطرف كردن اشكالات و بر گرداندن دوباره آن به زبان انخليسى توسط دو مترجم ديخر مسلط به زبان انخليسى با نسخه اصلى ابزار مقايسه شد، مقايسه نسخه انخليسى تهيه شده با نسخه اصلى به لحاظ يكسانى مفهومى در طى جلسهاى با حضور محققين و مترجمين و اعمال اصلاحات لازم در صورت نياز در نسخه فارسى اعمال شد. در نهايت آزمون مقدماتى ابزار به منظور بررسى مناسب بودن آن براى دركك سالمندان، تعيين زمان پِاسخدهى و اصلاح اشكالات احتمالى روى .r سالمند اجرا شد. نهايتاً
اين كه اين اختلالات در افراد سالمند بيشتر مىشود، اما آنها به دليل اينكه نشانها را به عنوان يروسه طبيعى سالمندى در نظر مى گيرند، تمايل كمترى به مراجعه براى دريافت خدمات مشاوره نشان مىدهند و به همين علت مىتواند از نظر صرف هزينه در مراحل بعدى و بار مراقبتى، فشار مضاعفى را روى دولت و خانو ادهها

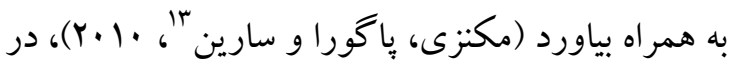
نتيجه تمايل سالمندان و رغبت آنها براى كرفتن مشاوره در زمينه خدمات مربوط به سلامت روانى قبل از بروز علائم، مىتواند هم براى آنها، هم براى خانوادههاى آنها و هم براى اقتصاد كشور بسيار مفيد باشد. بس وجود يرسشنامه يا ابزارى در اين زمينه كه بتواند تمايل و نكرش سالمندان به گرفتن خدمات روانشناختى حرفهاى را ارزيابى كند ضرورى به نظر مىرسد. در نهايت مطالعه حاضر به دنبال اين مقصود است كه آيا مقياس نكرش نسبت به دريافت خدمات روانشناختى حرفهاى در سالمندان ايرانى از روانسنجى مناسبى برخوردار است؟

\section{روش}

يزّوهش حاضر يكك مطالعه مقطعى (توصيفى) است كه به بررسى ويز گیىهاى روانسنجى ابزار مىيردازد. جامعه آمارى اين يثوهش را سالمندان زن و مرد بالاى 9 سال شهر تهران در سال IM9V. تشكيل دادند. نمونه مورد مطالعه از سالمندان مقيم جامعه شهر تهران به روش نمونه گيرى خوشه اى جند مرحله اى انتخاب شد. براى اين منظور ابتدا تهران به ه بخش (شمال، جنوب، شرق، غرب و مركز) تقسيم شدند، سيس به صورت تصادفى از هر بخش يكى منطقه و از هر منطقه يكك محله انتخاب شدند. در نهايت سؤالات مقياس از سالمندان ساكن در جامعه كه به مكانهاى عمومى، 
و ميزان يذيرش مفهوم تمايل به خدمات رواندرمانى براى كمكك به مشكلات شخصى و عاطفى را ارزيابى مى كند. ياسخدهند كان ميزان توافق خود را با موارد مثبت بيانشده مانند (اخر در اين مرحله از زندكى دهّار بحران عاطفى جدى بشوم، اطمينان خواهم داشت كه مىتوانم آسودگى خاطر را در رواندرمانى ببينم) و جملات منفى مانند (در نخرش فردى كه مايل به مقابله با تضادها و ترسهاى خود بدون توسل به كمكك مكري حرفهاى است، جيز قابل تحسينى وجود دارد) با استفاده از يك ليكرت f درجهاى (مخالف = · تا حدودى مخالف =ا، تا حدودى موافق = و و موافق =r ب بيان

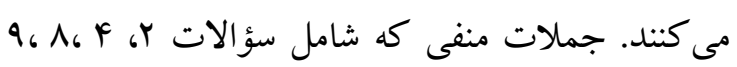
، ال است به صورت معكوس نمره خذارى مىشوند

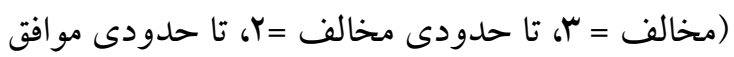
=ا و موافق =•). دامنه نمرات مقياس بين · تا ·ـ است.

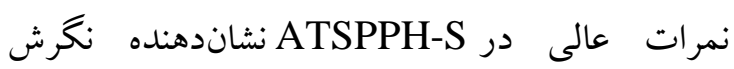
مطلوبتر نسبت به دريافت خدمات روات روانشناختى

$$
\text { حرفهاى است (جوزف، · •(Y). }
$$

در مقياس جديد و كوتاه كه بر روى نمونه دانشجويان

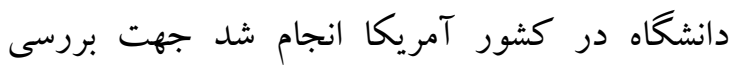
يايايى ابزار از روش آزمون باز آزمون به فاصله يكك ماه

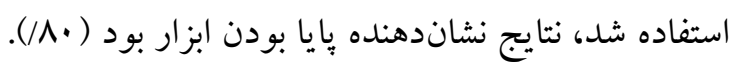

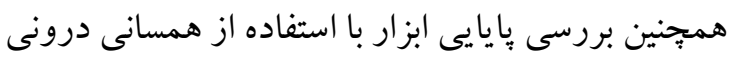

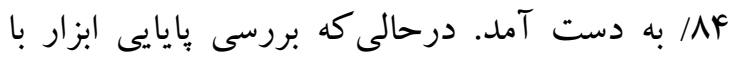
استفاده از روش آزمون باز آزمون به فاصله يكك ماه

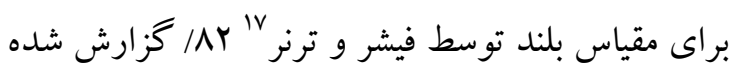
بود (فيشر و فارنيا، 1990). در مطالعهاى كه توسط جوزف انجام شد بررسى پايايى ابزار با استفاده از

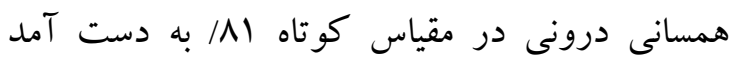

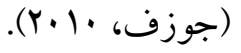

\footnotetext{
${ }^{17}$. Fischer \& Turner
}

يرسشنامهها بعد از ويرايش نهايى و وِ بس از گرفتن رضايت كتبى و توضيح اهداف يثوهش براى افراد سالمند توسط دانشجويان باتجربه رشتهاى مشاوره و روانشناسى اجرا شد. همجنين روايى ساختارى

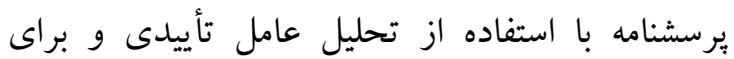
بررسى روايى يِش بين از ابزار شاخص بهزيستى

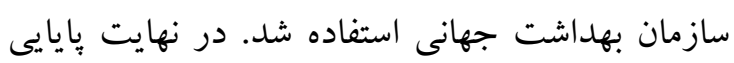
(همسانى درونى) مقياس نيز با استفاده از آلفاى

$$
\text { كرونباخ بررسى شد. }
$$
با توجه به اينكه مقاله حاضر بركرفته از يكك طرح

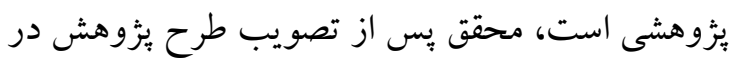

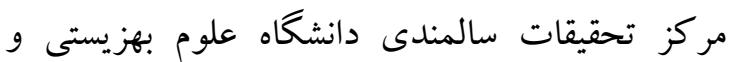
توانبخشى تهران اقدام به اخذ مجوز لازم از كميته

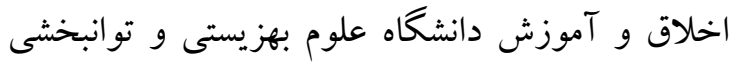

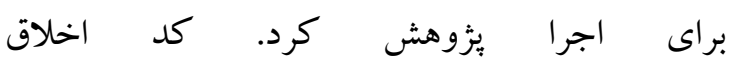

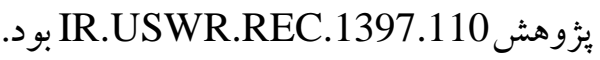

ابزار يرسشنامه اطلاعات جمعيت شناختى: شامل اطلاعات: سن، جنسيت، وضعيت تأهل، وضعيت اشتغال (در دوران قبل از بازنشستخى)، ميزان تحصيلات و دريافت مشاوره و... از طريق اين برسشنامه گرد آورى شد.

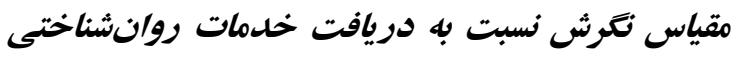

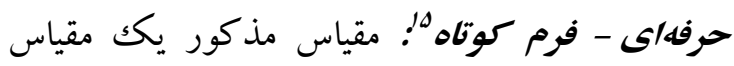

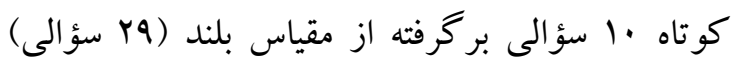

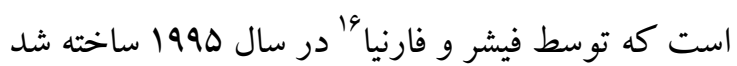

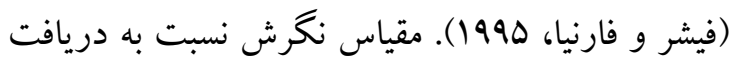
خدمات روانشناختى حرفهاى- فرم كوتاه، يكك مقياس خود كزارشى است كه اعتقاد كلى در مورد ارزش رواندرمانى براى كمكك به مشكلات شخصى و عاطفى

15. Attitudes Toward Seeking Professional Psychological Help Short Form (ATSPPH-S)

${ }^{16}$. Fischer \& Farina 
است (آواتا، بيج، يوشيدا، هيرايى، سوزوكى، ياماشيتا و

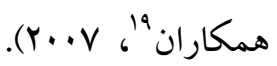

روش تجزيه و تحليل دادهها: بهطور كلى تحليل نتايج با

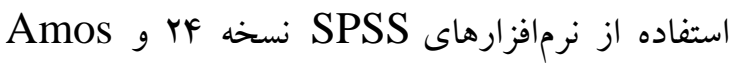
نسخه بr انجام شد. در تحليلها شاخصهاى تمايل مركزى و براكندگى براى متغيرهاى كمى، بررسى لهی روايى ظاهرى بنا به ارزيابى متخصصان، بررسى تحليل

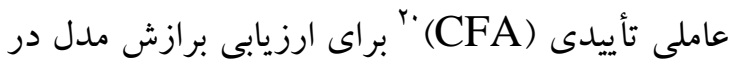
روايى ساختارى، بررسى روايى بيشبين با استفاده از ضريب همبستكى و محاسبه ضريب آلفاى كرونباخ به منظور ارزيابى همسانى درونى مقياس بررسى شد.

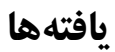

بررسى ويز گیىهاى جمعيت شناختى سالمندان مورد

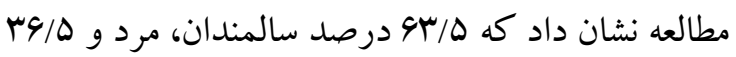
درصد سالمندان زن بودند. 9Y/ه درصد سالمندان متأهل بودند و ه r/ه درصد سالمندان فقط با همسرشان زندگى مى كردند. اكثريت سالمندان داراى سطح تحصيلات ابتدايى-راهنمايى يا متوسطه- دييلم بودند. همجِنين MV درصد سالمندان مورد مطالعه بازنشسته بودند. در زمينه دريافت خدمات مشاوره، همان كونه كه در جدول ا مشاهده مىشود M M درصد سالمندان به ردميه مشاور مراجعه نكردهاند. درحالى كه نيمى از سالمندان نكرش خوب و خيلى خوبى را نسبت به خدمات

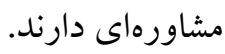

19. Awata, Bech, Yoshida, Hirai, Suzuki, Yamashita \& et al ${ }^{20}$. Confirmatory factor analysis

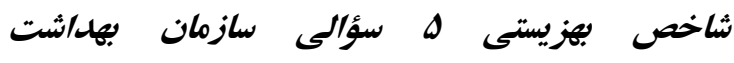
جهانس WHO-5' نشست سازمان بهداشت جهانى در استكهلم به عنوان يروزةاى براى اندازهگيرى بهزيستى در مراقبت از سلامت بيماران ارائه شد. شاخص بهزيستى سازمان جهانى بهداشت مقياسى كوتاه متشكل از هـ سؤال خود كزارشى است كه بر اساس يكك ليكرت 9 درجهاى از • (هيجوقت) تا ها (هميشه) ميزان بهزيستى رادر قالب جملاتى مثبت طى دو هفته گذشته را اندازهيرى مى كند. نمرات كل مقياس در طيفى از · · (عدم بهزيستى) تا مه (بالاترين بهزيستى) قرار مى كيرد.

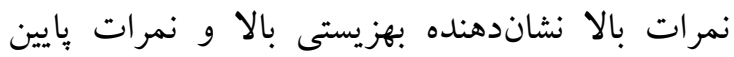

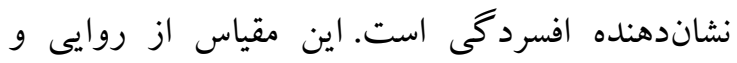
هايايى بالايى جهت اندازهگيرى بهزيستى ذهنى و ولنى

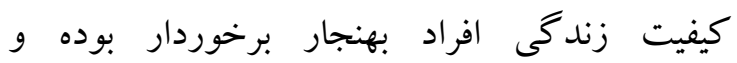
هنجاريابى آن در ايران نيز به عمل آمده است. نتايج تحليل عاملى اكتشافى و تأييدى نشان داد كه ساختار عاملى اين شاخص تكك عاملى است. همسانى درونى سؤالات اين شاخص بالا و ميزان آلفاى كرونباخ آن

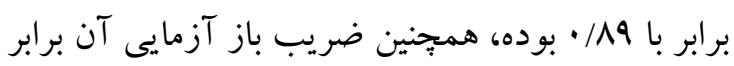

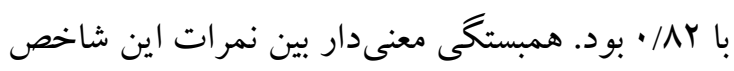
با نمرات شادكامى بيانگر روايى همخراى مناسب دمبن با نمرات افسردگى نشاندهنده روايى واگرايى (هV) مناسب (191/.-) بود (دهشيرى و موسوى، هوب1).

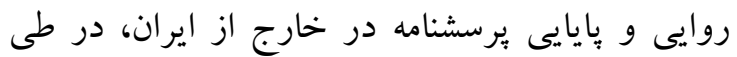
مطالعهاى در كشور زاين نشان داد كه ضريب آلفاى كرونباخ ه1/ • و تجزيه و تحليل عاملى مقياس تنها يكك عامل را نشان داده بود. همجنين همسانى درونى مقياس

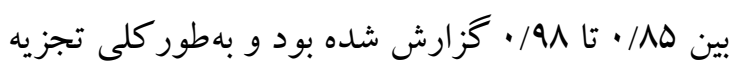

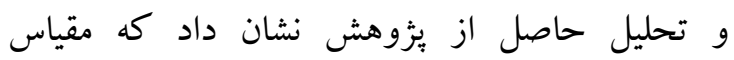
بهزيستى ه سؤالى از روايى و بايايى مطلوبى برخوردار

18. 5-Item World Health Organization Well-Being Index 


\begin{tabular}{|c|c|c|c|}
\hline درصد & فراوانى & طبقه & متغير \\
\hline ir & YF & بله & \multirow[t]{4}{*}{ مراجعه به روانشناس يا مشاور } \\
\hline$M$ & IV9 & خير & \\
\hline$r$. & f. & خيلى خوب & \\
\hline$M F / D$ & 99 & خوب & \\
\hline rV & $\Delta F$ & متوسط & \multirow{3}{*}{ خدرش كلى نسبت به دريافت مشاوره و روانشناسى } \\
\hline $\mid r / \Delta$ & ro & بد & \\
\hline 9 & Ir & خيلى بد & \\
\hline
\end{tabular}

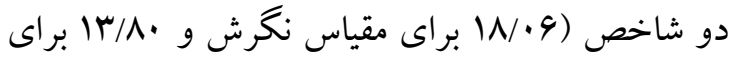
در جدول r ميانخين و انحراف استاندارد دو مقياس

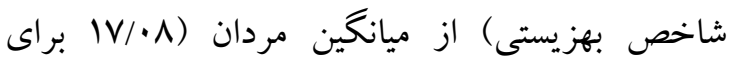
نكرش نسبت به دريافت خدمات روانشناختى و ولهن

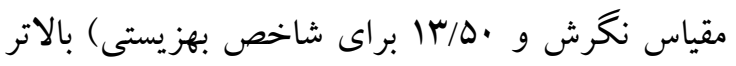
شاخص بهزيستى سازمان بهداشت جهانى در دو گروه مردان و زنان به تفكيك جنس ارائه شده است. مقايسه است. ميانگينهاى دو گروه نشان داد كه ميانخين زنان در هر

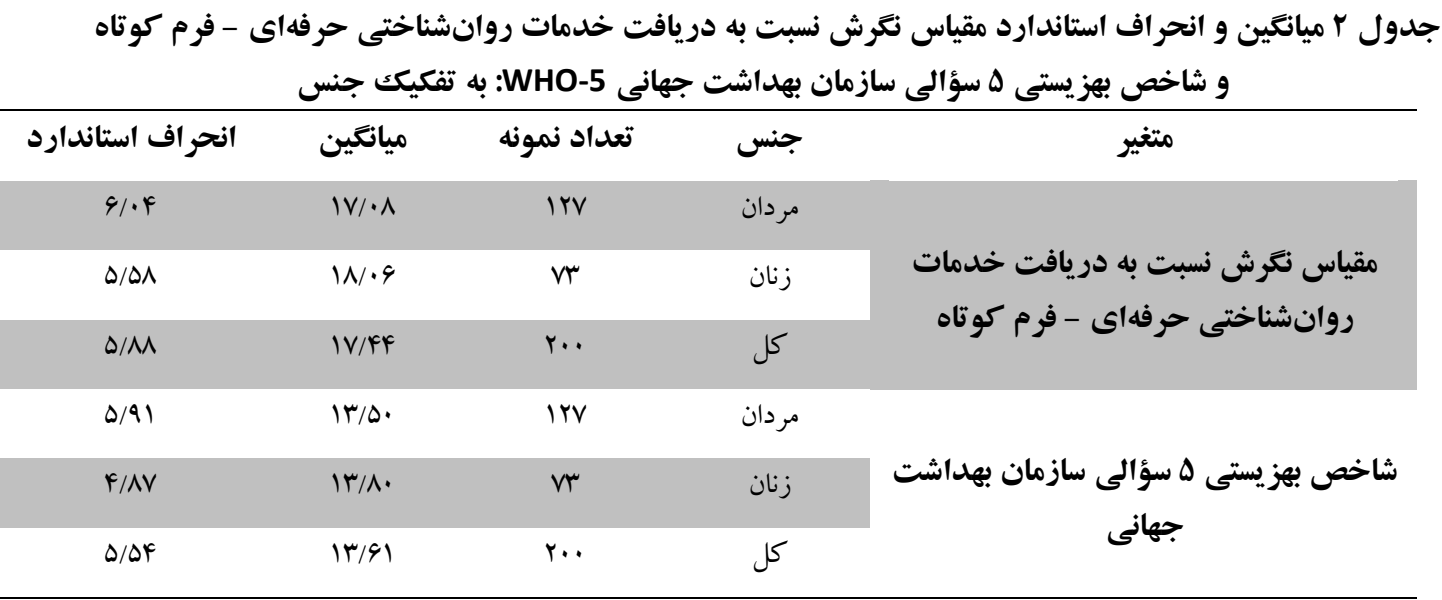

جهت تعيين روايى تأييدى از نرمافزار AMOS استفاده شد، همان گونه كه در نمودار ا نشان داده شده تهري

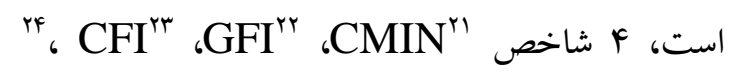
مربوط به تحليل عاملى تأييدى (CFASEA

\footnotetext{
${ }^{21}$.Chi square goodness of fit/ minimum value of the discrepancy

22. Goodness of fit index

${ }^{23}$.Comparative fit index

24 . Root mean square error of approximation
}

تجزيه و تحليل روايى ظاهرى (ساده بودن و واضح

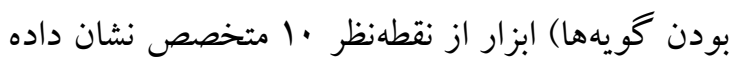
شد كه فقط آيتم جهار از نكاه يك متخصص يبيجيده

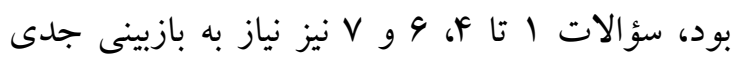
داشت كه با مشورت متخصصان، اصلاح، سادهتر و بون واضحتر شدند اما در كل سؤالات از نكاه متخصصان ساده يا كاملاً ساده و از طرفى ديخر واضح و كاملاً واضح بودند. 


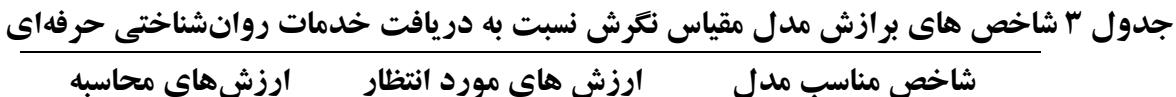

شده در مدل

\begin{tabular}{|c|c|c|}
\hline T/Yrq & بِياين تر از ه & CMIN \\
\hline.$/ 9 k T$ & 9/• و بالاتر & CFI \\
\hline . /9Y9 & ه/· و بالاتر & GFI \\
\hline$\cdot / \cdot \mathrm{Va}$ & بايين تر از ^••• & RMSEA \\
\hline
\end{tabular}

روانشناختى حرفهاى را در ميان سالمندان مورد مطالعه

$$
\text { تأييد كرد (نمودار ()). }
$$

تحليل عاملى تأييدى، تككبعدى (بدون زير مقياس) بودن مقياس نخرش نسبت به دريافت خدمات

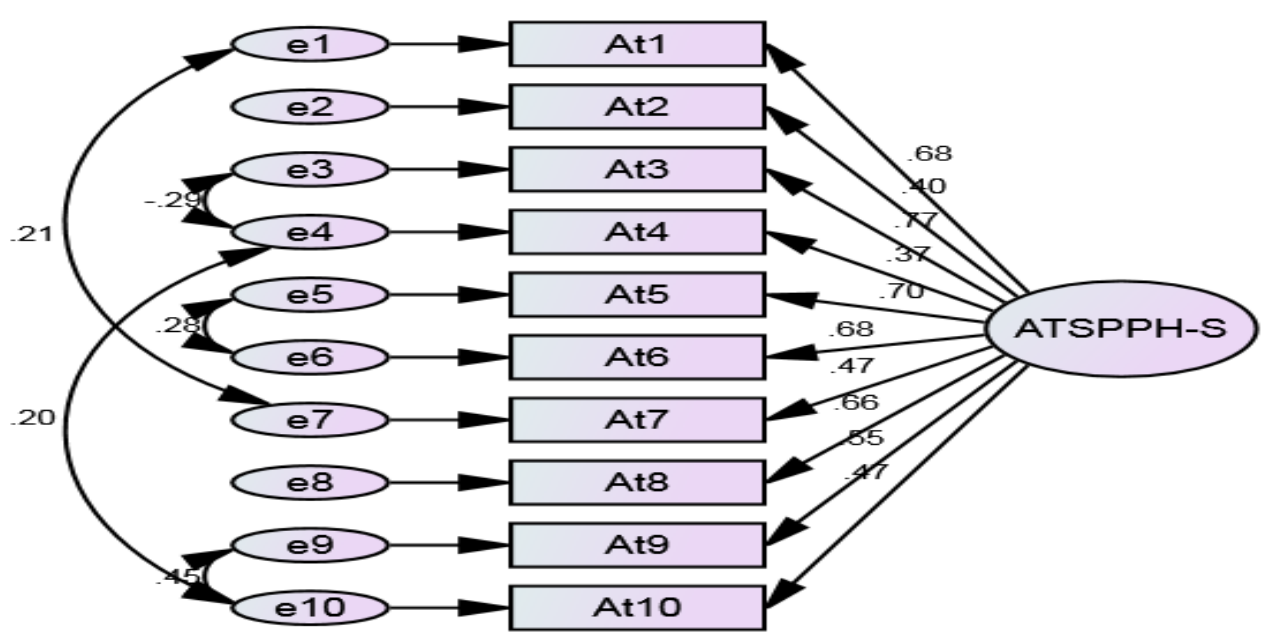

ATSPPH-S: Attitudes toward seeking professional psychological help scale-short form

CMIN $(<5)=2.229 ; \operatorname{GFI}(>.9)=.929$ CFI $(>.9)=.943 ;$ RMSEA $(<.08)=.079$

نمودار ا روايى تأييدى (CFI)

معنى دار بين اين دو متغير تأييد مىشود. به عبارتى ديخر

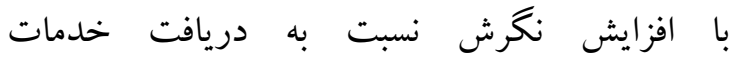
روانشناختى، بهزيستى سالمندان نمونه مورد بررسى نيز

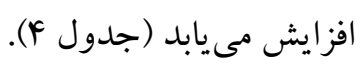

به منظور روايى بيش بين از آزمون ضريب همبستخى

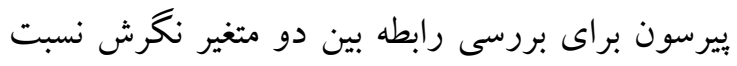

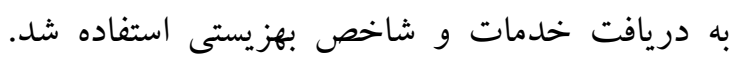

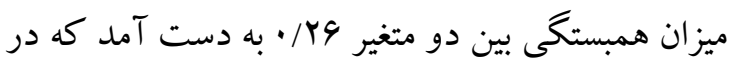
سطح l • • • معنىدارى بود. يس وجود رابطه مثبت و

جدول f آزمون ضريب همبستكى بيرسون براى بررسى رابطه بين نكرش نسبت به دريافت خدمات

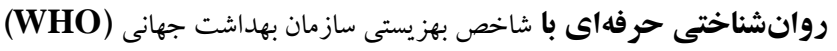


را نشان مىدهد. ضريب آلفاى كرونباخ كل برسشنامه در سطح مطلوب و برابر با AF/ • بود.
جدول ه، نتايج بررسى همسانى درونى يرسشنامه نحرش نسبت به دريافت خدمات روانشناختى حرفهاى

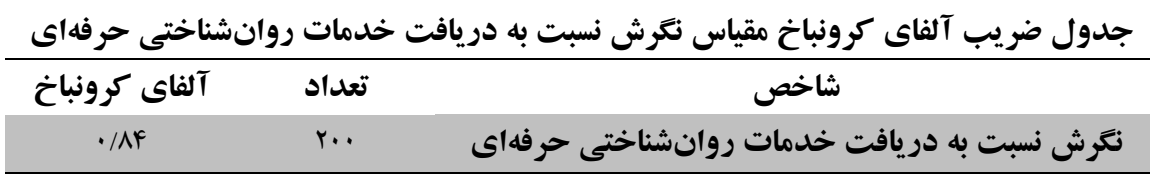

روى سالمندان بود. در يثوهش حاضر از يرسشنامه مذكور با ترجمه دقيق و مناسب و ساده از زبان اصلى به زبان فارسى، روايى صورى مطلوبى از نخاه متخصصان به دست آمد. در كل آيتمها هم از نظر ساده بودن و هم از نظر واضح بودن بررسى شدند و به جز يكك يا دو مورد، همه آيتمها ساده و واضح بودند. آيتمهايى كه نياز به بازبينى جزئى داشتند اصلاح شدند و براى استفاده بر روى نمونه سالمندان واضح و سادهتر

شدند.

جهت بررسى روايى ساختارى، تحليل عاملى تأييدى تككبعدى (تكك مقياسى) بودن يرسشنامه نخرش نسبت به دريافت خدمات روانشناختى حرفهاى در نمونه سالمندان را تأييد كرد. به لحاظ نظرى نيز برسشنامه

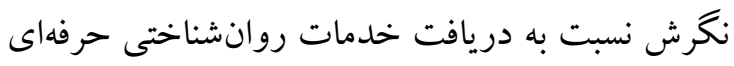
داراى يك بُعد بوده و نكخرش كلى (ATSPPH-S) نسبت به خدمات را نشان مىدهد. در مطالعه فيشر و فارنيا سازنده مقياس نيز يك بعد تأييد شده است (فيشر

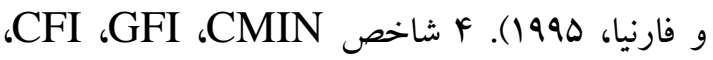
مربوط به تحليل عاملى تأييدى (CFASEA سطح معنىدارى مطلوبى داشتند و نشاندهنده سطح مطلوب برازش مدل بودند. در واقع هر ده سؤال يرسشنامه ATSPPH-S با هم نغرش كلى سالمندان مورد مطالعه را نسبت به دريافت خدمات روانشناختى
همجنين نتايج ضرايب مربوط به آلفاى كرونباخ به

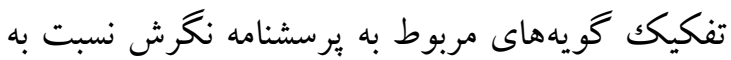
دريافت خدمات روانشناختى حرفهاى نشان داد كه با حذف هيج كدام از سؤالات ميزان همسانى درونى برسشنامه تفاوتى نخواهد كرد؛ بنابراين همسانى درونى تمامى سؤالات يرسشنامه جهت سنجش نكرش نسبت به دريافت خدمات روانشناختى حرفهاى در ارتباط با ديخر سؤالات مورد تأييد قرار مى گيرد.

هدف بيزوهش حاضر بررسى ويز گیىهاى روانسنجى مقياس نخرش نسبت به خدمات روانشناختى حرفهاى در نمونهاى از سالمندان ايرانى بود. نتايج يثوهش

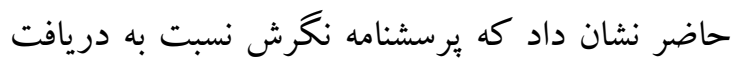
خدمات روانشناختى حرفهاى در نمونهاى از سالمندان ايرانى روايى و يايايى مناسبى دارد. يرسشنامه نخرش نسبت به دريافت خدمات روانشناختى حرفهاى به جهت تعداد كم آيتمهاى آن (·• آيتم) سبب افزايش

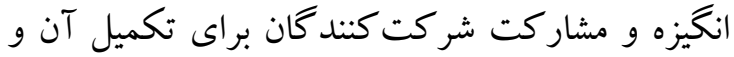
همجنين كاهش خستخى آنها خواهد شد. سهولت استفاده از اين ابزار به سبب ويزگگىهاى آن و و علاقهمندى محققان به استفاده از آن در انجام مطالعات يثوهشى باعث انتخاب و استفاده از آن در ايران و بر 
نمونهاى از آمريكايىهاى جامائيكايى، AV/ • گزارش شد. همجنين يافتهاى يُزوهش همسو با يافتهاى مطالعات

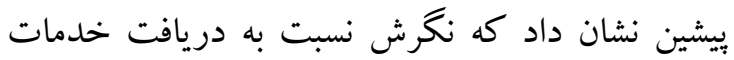
روانشناختى حرفهاى در زنان سالمند بيشتر بود

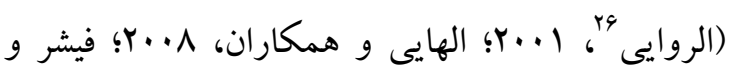
فارنيا، 1990 و فيشر و ترنر، ·19V). در اين مطالعه

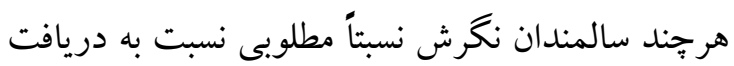

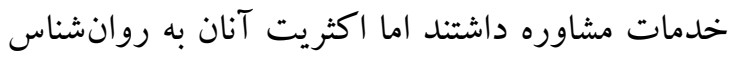
مراجعه نمى كردند. در نتايج ساير مطالعات مانند مطالعه الهايى و همكاران نيز يافتها نشان داد كه ارتباط

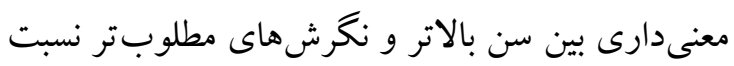
به درمان وجود داشت (الهايى و همكاران، م+•r). اينكه جرا سالمندان كمتر به دنبال خدمات روانشناختى هستند، همانطور كه در تحقيقات بيشين مشاهده شده

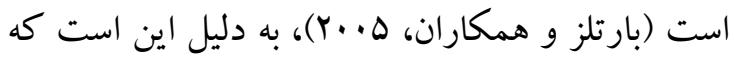
آنها علائم و مشكلات بيش رو را جزء فرايند طبيعى و مدرات

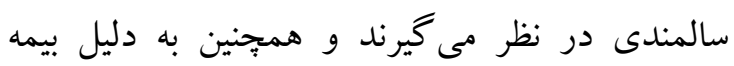

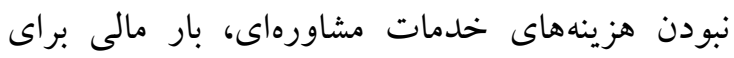

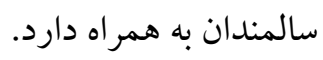

\section{نتيجه كيرى}

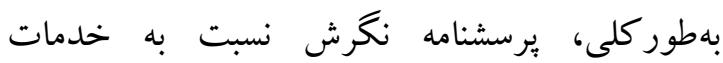
روانشناختى حرفهاى داراى روايى و بايايى مطلوبى در نمونهاى از سالمندان ايرانى است كه به دليل كوتاه،

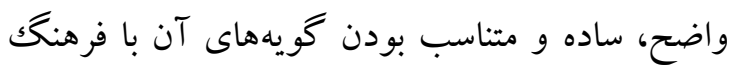
ايرانى قابل استفاده توسط ئزوهشكران، ارائهدهند كان خدمات مشاوره (در راستاى اهداف يُوهشى) و

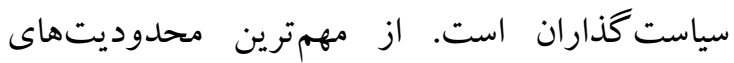

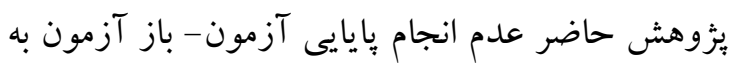

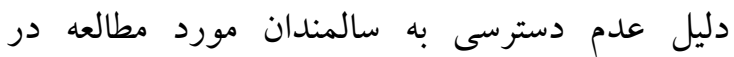

${ }^{26}$. Al-Rowaie
تشكيل دادند. در بثزوهش حاضر به منظور روايى بيش

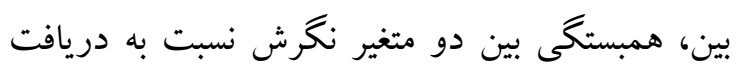
خدمات روانشناختى و شاخص بهزيستى سازمان بهداشت جهانى سنجيده شد. شاخص بهزيستى شاخصى است كه با نمرات شادكامى داراى روايى همخراى

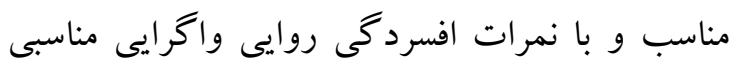
دارد؛ بنابراين به عنوان يك متغير بيشبينى شونده مناسب در ارتباط با نخرش نسبت به دريافت خدمات روانشناختى محسوب مى شود. در يُوهش حاضر ميزان همبستخى بين دو متغير نخرش نسبت به دريافت خدمات روانشناختى و شاخص بهزيستى و وك/. به دست آمد كه نشان از رابطه مثبت و معنىدار بين اين

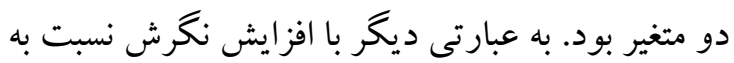

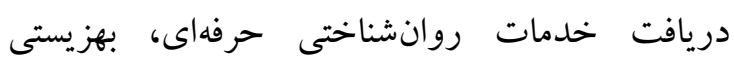
سالمندان نمونه مورد بررسى نيز افزايش مىيابد؛

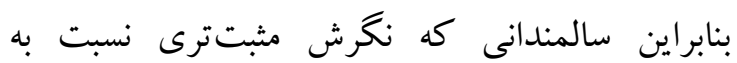

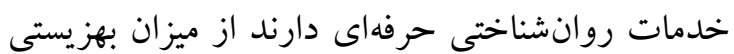
بالاترى برخوردار هستند. ضريب آلفاى كرونباخ براى بررسى همسانى درونى برونى يرسشنامه ATSPPH-S برابر با AF/ بو بود كه

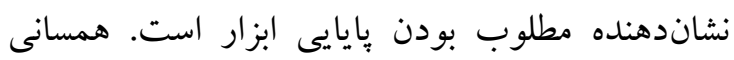

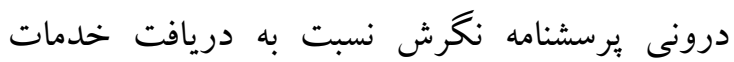
روانشناختى حرفهاى در نمونه سالمندان مشابه ساير تحقيقات روانسنجى ابزار بود (الهايى و همكاران،

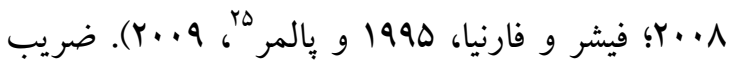
آلفاى كرونباخ در مطالعه الهايى و همكاران در نمونه

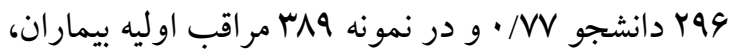
/ PA به دست آمد. در مطالعه فيشر و فارنيا بر روى

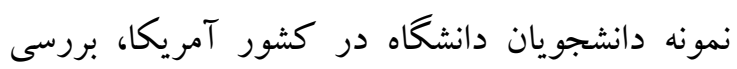
يايايى ابزار با استفاده از همسانى درونى AF/ به دست

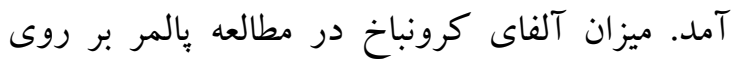


patients: A randomized clinical trial. Clinical Nutrition . 38(5), 2065-2070.

Awata S, Bech PER, Yoshida S, Hirai M, Suzuki S, Yamashita M, \& Oka Y. (2007). Reliability and validity of the Japanese version of the World Health Organization-Five Well-Being Index in the context of detecting depression in diabetic patients. Psychiatry and clinical neurosciences, 61(1), 112-119.

Bartels SJ, Blow FC, Brockmann LM, \& Van Citters AD. (2005). Substance abuse and mental health among older Americans: The state of the knowledge and future directions. Rockville, MD: Westat.

Conner KO, Copeland VC, Grote NK, Koeske G, Rosen D, Reynolds III CF, \& Brown C. (2010). Mental health treatment seeking among older adults with depression: the impact of stigma and race. The American Journal of Geriatric Psychiatry, 18(6), 531543.

Costa PT, \& McCrae RR. (1988). Personality in adulthood: a six-year longitudinal study of self-reports and spouse ratings on the NEO Personality Inventory. Joumal of personality and social psychology, 54(5), 853.

Darabi S, \& Torabi F. (2017). Analysis and Comparison of Aging Population in Europe and Asia During 1950 to 2015. Salmand: Iranian Joumal of Ageing, 12(2), 30-43. doi:10.21859/sija-120128.

Dehshiri Gh, \& Mousavi SF. (2016). An Investigation into Psychometric Properties of Persian Version of World Health Organization Five Well-being Index. Journal of Clinical Psychology, 8(2), 67-75. doi:10.22075/jcp.2017.2237.

Diala C, Muntaner C, Walrath C, Nickerson KJ, LaVeist TA \& Leaf PJ. (2000). Racial differences in attitudes toward professional mental health care and in the use of services. American Journal of Orthopsychiatry, 70(4), 455-464.

Elhai JD, Schweinle W, \& Anderson SM. (2008). Reliability and validity of the attitudes toward seeking professional psychological help scale-short form. Psychiatry research, 159(3), 320-329.

Fischer EH, \& Farina A. (1995). Attitudes toward seeking professional psychologial help: A

$$
\begin{aligned}
& \text { مكانهاى عمومى شهر تهران بود. ازاينرو بيشنهاد } \\
& \text { مىشود در مطالعات آتى ثبات زمانى ابزار بررسى شود. } \\
& \text { همجِنين متخصصان حوزه سلامت روان، مشاوران و } \\
& \text { روانشناسان مىتوانند از وبرسشنامه ATSPPH-S } \\
& \text { جهت مطالعات يزوهشى در راستاى سنجش نخرش } \\
& \text { سالمندان نسبت به خدمات مشاورهاى و عوامل مرتبط } \\
& \text { با آن بهره بخيرند. اين مقياس به دليل گويههاى } \\
& \text { محدود، زمان كو تاهى براى تكميل شدن نياز دارد. در بره } \\
& \text { نهايت ييشنهاد مىشود، يزوهشخران در مطالعات آتى برى } \\
& \text { روايى و بايايى ابزار را در سالمندان مقيم آسايشگاهها و }
\end{aligned}
$$

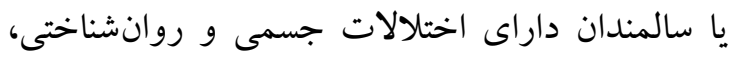

$$
\begin{aligned}
& \text { بررسى كرده و نتايج آن را با سالمندان مقيم جامعه } \\
& \text { مقايسه و تحليل نمايند. }
\end{aligned}
$$

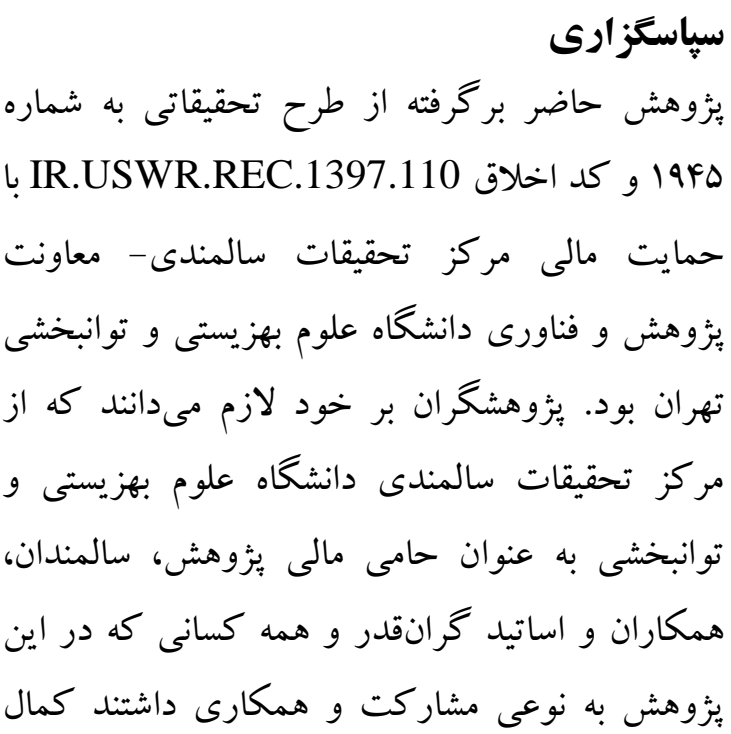$$
\text { تشكر را داشته باشند. }
$$

\section{References}

Al-Rowaie OO. (2001). Predictors of attitudes toward seeking professional psychological help among Kuwait university students. (Doctoral dissertation, Virginia Tech).

Alavi NM, Khademalhoseini S, Vakili Z, \& Assarian F. (2019). Effect of vitamin D supplementation on depression in elderly 
shortened form and considerations for research. Joumal of College Student Development.

Fischer EH, \& Tumer JI. (1970). Orientations to seeking professional help: Development and research utility of an attitude scale. Joumal of consulting and clinical psychology, 35(1p1), 79.

Joseph J. (2010). Willingness to seek professional psychological help among Canadians of African descent: A culturally based helpseeking model. Electronic Theses and Dissertations.

Kooshyar H, Shoorvazi M, Dalir Z, \& Hoseini S. (2015). Surveying Health-Related Quality of Life and Related Factors in the Diabetic Elderly in Mashhad in 2013. Joumal of Rafsanjan University of Medical Sciences, 14(3), 175-188.

Mackenzie CS, Pagura J, \& Sareen J. (2010). Comelates of perceived need for and use of mental health services by older adults in the collaborative psychiatric epidemiology surveys. The American Journal of Geriatric Psychiatry, 18(12), 1103-1115.

Osmanovic-Thunström A, Mossello E, Åkerstedt T, Fratiglioni L, \& Wang HX. (2015). Do levels of perceived stress increase with increasing age after age 65 ? A population- based study. Age and ageing, 44(5), 828834.

Palmer GJ. (2009). Examination of the reliability and validity of the Attitudes Toward Seeking Professional Psychological Help Scale (ATSPPHS) among Jamaican Americans. http://digitalrepository.unm.edu/educ_ifce_e tds/1

Pepin R, Segal DL, \& Coolidge FL. (2009). Intrinsic and extrinsic barriers to mental health care among community-dwelling younger and older adults. Aging \& Mental Health, 13(5), 769-777.

Plichta SB, Kelvin EA, \& Munro BH. (2013). Munro S statistical methods for health care research: Wolters Kluwer Health/Lippincott Williams \&Wilkins.

Renn BN, \& Areán PA. (2017). Psychosocial treatment options for major depressive disorder in older adults. Cument treatment options in psychiatry, 4(1), 1-12.

Robb C, Haley W, Becker M, Polivka L, \& Chwa HJ. (2003). Attitudes towards mental health care in younger and older adults: Similarities and differences. Aging \& Mental Health, $7(2), 142-152$.

Statistical Center of Iran. Population and Housing Census. (2017). Available from: https://www.amar.org.ir/. Accessed Jan . 